Open Access Refereed E-Journal \& Indexed \& Puplishing

Article Arrival : : 18/01/2020

Review Article

Related Date $\quad: 10 / 03 / 2020$

Published : : 10.03 .2020

Doi Number doi $\quad$ http://dx.doi.org/10.26449/sssj.2048

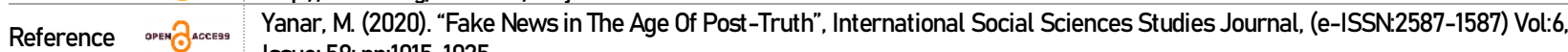
Issue: 58; pp:1015-1025

\title{
FAKENEWSINTHEAGE OFPOST-TRUTH ${ }^{1}$
}

\section{Hakikat-Sonrasi Dönemde Yalan Haberler}

\author{
Dr. Muhsin YANAR \\ Sabancı University, Istanbul/TURKEY \\ ORCID ID: https://orcid.org/0000-0003-2523-608X
}

\section{ABSTRACT}

The definition of 'post-truth', according to Oxford Dictionaries, is those objective facts are today less effective and powerful in structuring public or masses' opinions than personal emotions and beliefs. The prefix post- does not come to mean 'after' but 'the end' or 'the death.' In other words, the word 'post-truth' comes to indicate 'the end, or the death of truth.' To put it differently, feelings and emotions 'matter more than facts.' Mass media and social media are the main promoters of post-truth or of the death of truth. This study investigates how much the public is exposed to and manipulated by these promoters and by fake news that comes out of these promoters. The study also aims to figure out how much literate the public is on reading fake news in the age of 'post-truth.' For this small-scale study, data was gathered from surveys both in Turkish and English. Data analysis and evaluation provided a small-scaled outcome to suggest further study.

Key Words: Fake News, Post-Truth, social media, public

\section{ÖZET}

Oxford Dictionaries 'hakikat-sonrası' terimini nesnel gerçeklerin bugün kamu veya kitle görüşlerini oluşturmada kişisel duygulara ve inançlara nazaran daha az güçlü ve etkili olması olarak tanımlar. Önek post- 'sonra' anlamından ziyade 'son' veya 'ölüm' anlamına gelir. Başka bir deyişle, 'hakikat-sonrası' terimi 'gerçeğin sonu ya da ölümü' anlamına gelir; duygular ve duygular 'gerçeklerden daha önemlidir'. Kitle iletişim araçları ve sosyal medya, hakikatsonrası veya hakikatin ölümümün ana destekçileridir. Bu çalışma, halkın bu destekleyiciler aracılığıyla yayılan sahte haberlere ne kadar maruz kaldığını ve manipüle edildiğini araştırmaktadır. Çalışma, ayrıca, halkın hakikat-sonrası çağda sahte haberleri okuma konusunda ne kadar bilgili olduğunu bulmayı amaçlamaktadır. Bu küçük ölçekli çalışma için hem Türkçe hem de İngilizce anketlerden veriler toplanmıştır. Veri analizi ve değerlendirme, ileri tetkik için küçük ölçekli bir sonuç sağlamıştır.

Anahtar Kelimeler: Sahte haber, hakikat-sonrası, sosyal medya, kamu

\section{INTRODUCTION}

Post-Truth is a term that denotes particular truths, ignoring the criteria that are related to evidence and reasoning, and explicitly lying to humanity. The age of post-truth is not about the idea of knowing the truth but is certainly about ignoring the existence of truth (McIntyre, 2018, p.31). The post-truth age contains fake news stories within itself, which modifies and transforms society's perception of truth and construct different reality. People begin to comprehend the environment with a truth that has no foundation. In the age of post-truth, the public gradually gets false information and is manipulated through mass media. Hence, lies replace or displaces truth. "Objectivity, Michiko Kakutani asserts, has been falling out of favor" (2018, p.17). Considering this, this study aims to investigate the public perspective on post-truth and fake news. It asks questions whether they know media manipulations or not, whether they can read these manipulations, can easily tract true and fake news or not, and lastly, whether they have any responses or solutions to these manipulations or not. Given these questions, the researchers have conducted small-scale research. The literature review part gathers and explains the key arguments of some significant figures in the field to structure the keystone of the study. The second part explains the methods, the participants, data collection and analysis. The last part gives a detailed discussion of the study and offers suggestions for further study.

\footnotetext{
${ }^{1}$ This collective research was conducted by the members of PROJ 201 offered by Foundational Development Directorate at Sabanc1 University in the Fall semester 2019. The research was supervised by Muhsin Yanar. The research members are; İlke Cengiz, Sina Demirci, Fatih Dilmit, Buse Ekebaş, Hikmet Emre Gülcü, Su Polen Uran, Ömer Faruk Usta, Gizem Fıçıcıoğlu, Eylül Onar, Zeynep Umucu.
} 


\section{LITERATURE REVIEW}

The concept of "post-truth" and fake news has an important impact on our lives today. Post-truth is, by definition, related "to circumstances in which people respond more to feelings and beliefs than to facts" (Oxford Learner's Dictionaries). The age of post-truth denotes "the decline of rational discourse", "the diminished role of common sense" and "fact-based policy" (Kakutani, p.30). The concept has become more and more prevalent after the Brexit and US presidential elections in 2016 (McIntyre, 2018, p.22). Lee McIntyre states that when this concept started to spread, people didn't care enough but when the Post-Truth starts to take more and more places in their life, they started to understand the seriousness of the Post-Truth (McIntyre, 2018, p.27). Post-Truth, likewise, is the expression of concern that is felt by people who take care of the truth and believe that it is under attack (McIntyre, 2018, p.28). Jean Baudrillard, in his book, In the Shadow of the Silent Majorities (1983), argues that people who lie about their purposes, which are to create a better society, to give their perspective to society and to increase societies' cultural level, shape society's perception of truth (Baudrillard, 1983, p.12). Society easily accepts and believes what they read, see or hear without even questioning. Ignorance now is fashionable for them. They desire experience out of ordinary things in their lives. Therefore, they count on a show instead of meaning. To illustrate, Klaus Croissant who is a German lawyer has been exiled from France the night when France's election game to join for the World Cup was broadcasted live. While hundreds of people were protesting his exile in front of the prison, 20 million people were in front of the screen. The World Cup has turned into a show for the society and they focused on the show instead of the lawyer's expulsion. Impassivity of these people's reasons is inexplicable, but still, there is one reason (Baudrillard, 1983, p.28). The reason is that the authority guides and hypnotizes society (masses) through football. At this point, the main motive is to manipulate society through contradictory news and to distract them from the truth (Baudrillard, 1983, p.14). This serves to simulacra. As Jean Baudrillard in Simulacra and Simulations defines that simulation is "the artificial reproduction of a tool, a machine, a system, a phenomenon-specific way of operation through a model or a computer program to examine, show or explaining" (Baudrillard, 1995, p.17). This concept spells the reproduction of the truth which has a lack of origin and reality with models, so is hyperreality. Simulacra is the aspect that desires to be perceived as reality, which does not conceal the truth but hides the absence of truth.

Moreover, Ralph Keyes addresses the absence of truth in his book The Post-Truth Era: Dishonesty and Deception in Contemporary Life: "[...] factual truth should submit to 'much greater truths'. It suggests that those who pursue greater truths, do not disapprove of honesty. Instead, they seek much bigger things; for a higher honesty that can be reached by lying. As it is obvious in the German lawyer case, the authority generates a universe of simulacra by using football simulation to make society more insensitive. Disneyland is a significant example of simulacra in terms of building a simulation which develops an illusion in people's minds. When people get into this imaginary universe, their emotions and ideas alter or metamorphose and they lost track of themselves (Baudrillard, 1995, p.28). It is akin to Marshall McLuhan's definition of the global village. He puts, "Ours is a brand-new world of all-at-once-ness. "Time" has ceased, "space" has vanished. [...a] simultaneous happening" (McLuhan, 1967, p.36). The world has turned into a fictional order because of technology and media. In this fictional world, a person can easily communicate with another person wherever s/he is, whenever s/he wants. As the distance between people and time became insignificant, the world has become a global village. People go to Disneyland to escape from reality; the fake simulacra and the illusion that the media creates. Those who realize this fiction and understand that there is nothing to do to alter the situation, feel lonely, alienated and fragmented. This situation is akin to the facts about fake news: the lie that humans have been able to create since the evolutionary process has given it a great power. (McIntyre, 2018, p.101) As people (authorities) are already familiar with the power of manipulation, they use fake news (any fake news), as a medium of manipulation, to shape people's perceptions (McIntyre, 2018, p.108) Ralph Keyes argues that the truth of lies can represent better than truth itself (Keyes, 2004, p.187). As people have been imposed and exposed to lies for years, lies have perceived as truth, which is the truth of lies. Thus, the truth of lies today has control over society instead of the truth itself. McIntyre states that people understand the power of the lie and try to manipulate societies as they would like to be. Instead of destroying the energy of the mass, the news always creates a growing mass. Instead of informing, shaping and structuring the news, as it claims to do, the news increasingly neutralizes the "social" and creates a mass that is insensitive and unresponsive to the content of the news with classic social institutions. (Baudrillard, 1983, p.22). 
Fake news denotes satiric, parodic, fabricated, manipulated and serves propaganda (Nielsen \& Graves, 2017; Tandoc et al., 2018). It "appropriates the look and feel of real news: from how websites look, to how articles are written, to how photos include attributions. Fake news hides under a veneer of legitimacy as it takes on some form of credibility by trying to appear like traditionally trusted content" (Zerfass, A., Tench, R., Verhoeven, P., Vercic, D., \& Moreno, A., 2018, p.16). Fake news is commonly not a mistake, it is created or formulated on sinister purpose (McIntyre, 2018, p.102). Politicians who change the truth for their purposes are fully conscious about what they do. Those are the ones who conceal, distort and end the truth. The greatest example for manipulation of the society is Donald Trump: in the case of Donald Trump's losing the U.S. elections in 2016, a phenomenon/scenario was created which claims that this defeat was planned towards him (McIntyre, 2018, p.30). Trump himself claimed that he has won a "massive landslide victory" at the electoral college, an uncertain claim. He also explained that in the election there had been three million false votes he had won" (Ball, 2017, p.32). This proves that political fake news exists and that it easily reaches huge social media users. After these elections, it becomes more evident that there is an increase in politicians' fake news, which changes the perception of society (with the medium) (McLuhan, 1967, p.30). As Marshall McLuhan suggests "the medium, or process, of our time, is reshaping and restructuring patterns of social interdependence and every aspect of our personal life. Everything is changing you, your family, your neighborhood, your education, your job, your government, your relation to "the others." And they're changing dramatically "(McLuhan, 1967, p.9). These days, the opportunities for telling lies are consistently available; the medium that hides a lie is abundant and punishment of getting caught is quite light. Hence, this increased people's ability to use the medium in a more effective and manipulative way for their benefits (Keyes, 2004, p.61). The perspectives of these authors and critics constitute the backbone of this conducted small-scaled research.

\section{METHODOLOGY}

The methodology reflects insight into the study itself. It explains the method, participants, data collection and analysis.

\subsection{Participants}

Participants in this study included 635 people from Turkey between the ages of 18 and 55. In this study all participants are volunteers, professionals, employees and students. The researchers asked the participants to fill out a short survey that aims to investigate the relationship between people and their interaction with mass media, social media, and fake news, and the researchers did ask no personal information.

\subsection{Data Collection}

The researchers prepared an online survey and sent to professionals, employees and students via a web link on the Sabanc1 University survey platform. The questionnaire consisted of ten questions, based on age, gender, and education levels of the volunteer participants. Additionally, it included questions about the use of social media, the frequency of watching television, and the habit of reading the newspaper and other scientific papers, and lastly, it consisted of questions about participants' familiarity with the concept of post-truth and their exposure to fake news. The survey used both the Turkish and English language. Sabanc1 University Foundational Development Directorate administration activated the survey for 4 weeks in November. In total, 1,236 respondents started the survey and 635 of them completed it. Answers from participants who could not complete were removed from the dataset. The evaluation is then based on 635 fully completed replies of the respondents. The researchers, for data analysis, used Lime Survey, open source on-line statistical survey web app written in PHP.

\section{DATA ANALYSIS AND RESULTS}

This part reveals the analyzed data and interpretations of the results. The researchers analyzed the 10 questions one by one to get a better and complete understanding of the public awareness of fake news, post-truth, and media manipulation. Firstly, Figure 1 and Figure 2 respectively show age, gender, and education level. Figure 3 indicates answers to the question of the news platform/s that the participants spend more time on. In Figure 4 points gender and age distributions of the most given answer to news platforms. Figure 5 and 6 shows the concepts of post-truth and fake news and respondents' familiarity with these concepts and their tendency to search for the truth of the news. Figure 7 demonstrates how the news platforms and fake news and their fakeness/falsity and truth are related. Figure 8 indicates the trust level of 
news platforms, and it measures the reliability and trust-ability of these platforms. Finally, the last figure measures which platform or who distort the truth most.

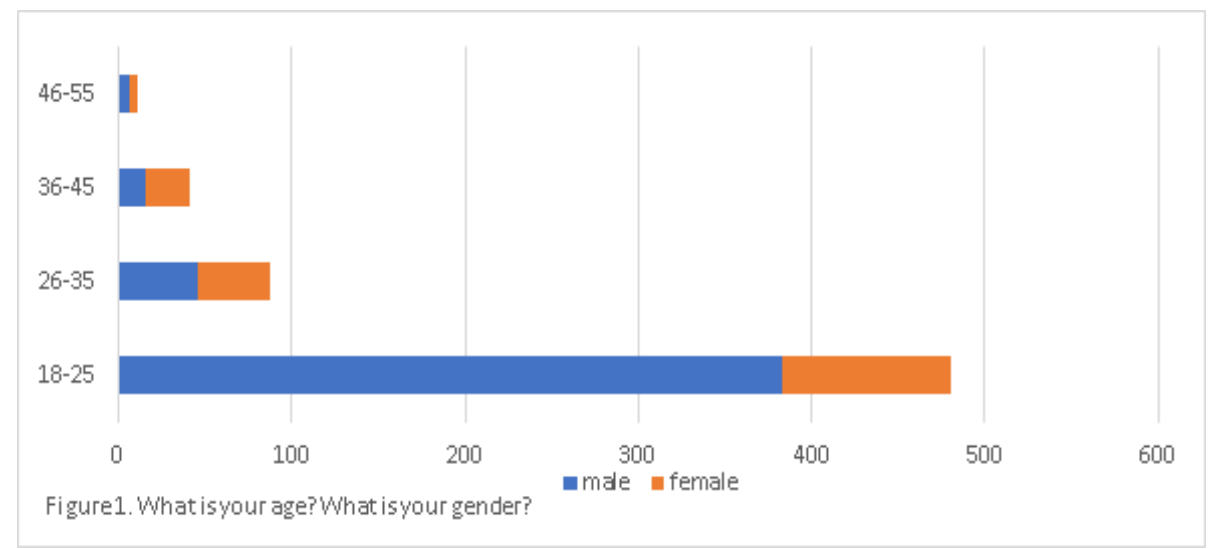

Figure 1 shows the age and gender distribution of the participants. The figure reveals that more than three quarters, $77.17 \%$, of the participants are between the ages of 18-25, while the participation in the 26-35 age group is $14.49 \%$. The ratio is lower in other age ranges. The percentage of the $36-45$ age group is $6.46 \%$. The lowest participation in the survey is in the $46-55$ age group, $1.89 \%$. Almost in each age group, the ratio of male participants is high. The 36-45 age group shows that the number of females is higher than males. However, the majority of the participants in the males, $71.02 \%$, and $26.61 \%$ of those are the females.

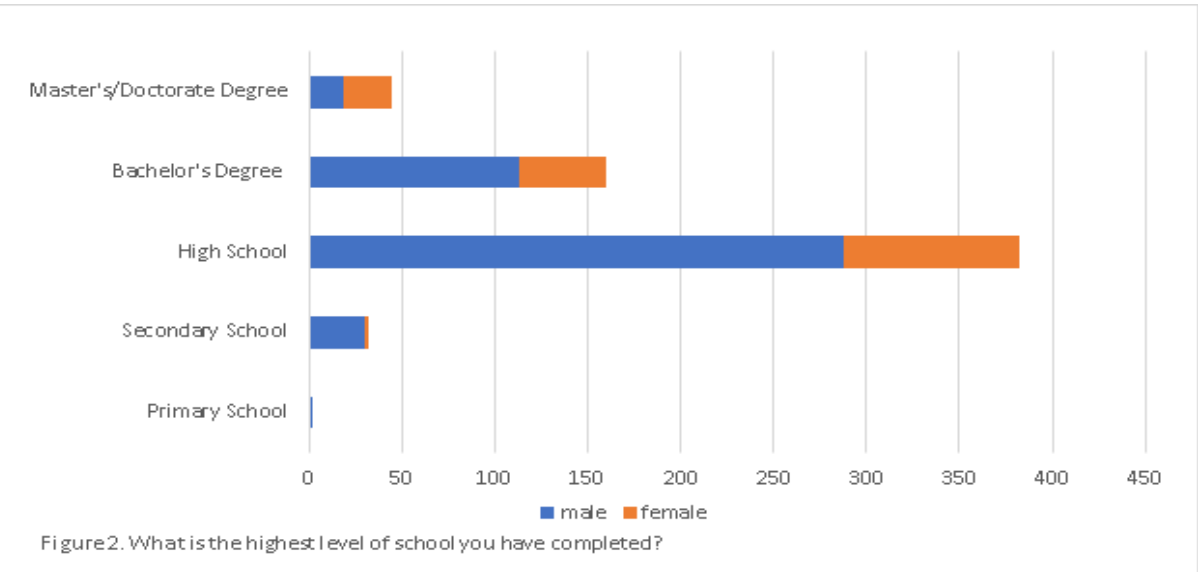

Figure 2 shows that the education level of the participants is generally at or above high school degree. More than half of 635 participants completed high school as the highest degree of education. Only 5.35\% of the participants are at the elementary or secondary school level. The general profile of the participants, between the age of $18-25$, is a college undergraduate.

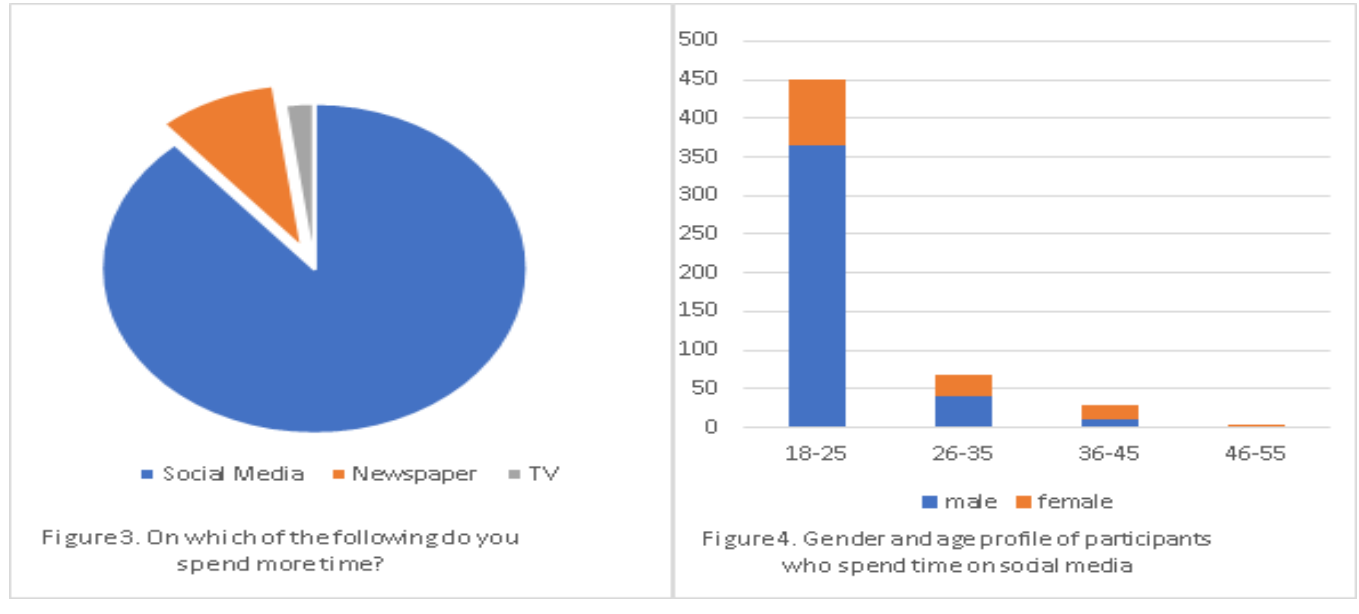


Figure 3 shows how the participants spend most of their time. And Figure 4 shows the ratio of the most given answer "social media" according to age and gender of the participants. In the 18-25 age group, 93\% of those spend their time on social media platforms. In the 18-25 age range, $95.30 \%$ of 383 male participants spend time on social media applications while this answer is given by $87.62 \%$ of 97 female participants. At the 26-35 group, $76 \%$ of the whole group picked social media as an answer to the question. $86 \%$ of the male participants in this group and $64 \%$ of the female participants spend their time on social media. $73 \%$ of the $36-45$ age group selected the social media as an answer to the question [MY1] and the rate of the male participants of this group is $68 \%$ while the female participants' rate is $76 \%$. At the $46-55$ age group, $60 \%$ of the female participants and $17 \%$ of the male participants (33.3\% of all group) spend time on online media platforms. [MY2] The first three age group spend time on social media platforms [MY3] in general. At the point when investigated, the time spent through social media lessens when age increases. The male participants in the first two age groups spend time more than the female participants. $1.4 \%$ of the $18-25$ age group; $5.43 \%$ of the $26-35$ age group; $2.43 \%$ of the $36-45$ age group and $17 \%$ of the 46-55 age group spend time on TV, and radio. $5 \%$ of the $18-25 ; 18,47 \%$ of the $26-35 ; 24,39 \%$ of the $36-45$ and half of the 46-55 selected paper, magazine/journal, book/research as an answer. The rate of the answer to "TV, radio" is lower in all age groups, which implies that TV/ radio has lost its power and popularity among age groups.

\begin{tabular}{|c|c|c|c|c|c|c|}
\cline { 2 - 6 } \multicolumn{1}{c|}{} & \begin{tabular}{c} 
Social \\
\cline { 2 - 6 }
\end{tabular} & Modia & $\begin{array}{c}\text { Scientific } \\
\text { Paper }\end{array}$ & $\begin{array}{c}\text { Immediate } \\
\text { Circle }\end{array}$ & $\begin{array}{c}\text { Never } \\
\text { Heard }\end{array}$ & \multicolumn{1}{c}{} \\
\cline { 2 - 6 } & 62 & 36 & 28 & 44 & 465 & Participants \\
\hline female & 16 & 14 & 8 & 17 & 114 & 169 \\
\hline male & 44 & 21 & 19 & 26 & 341 & 451 \\
\hline blank & 2 & 1 & 0 & 1 & 8 & 12 \\
\hline other & 0 & 0 & 1 & 0 & 2 & 3 \\
\hline
\end{tabular}

Figure5. Where have you heard the "Post-Truth" concept first?

Figure 5 examines the knowledge of both male participants and female participants about "Post-Truth". $71 \%$ of participants have not heard the term post-truth; 9.44 of participants (also $86 \%$ of them are using social media) have heard it from media. $6.77 \%$ of participants picked the option "immediate circle", which proves there are more people who have heard the term "post-truth." While 5.5\% of those have heard it through a book, only $4.4 \%$ of those know it through a scientific paper.

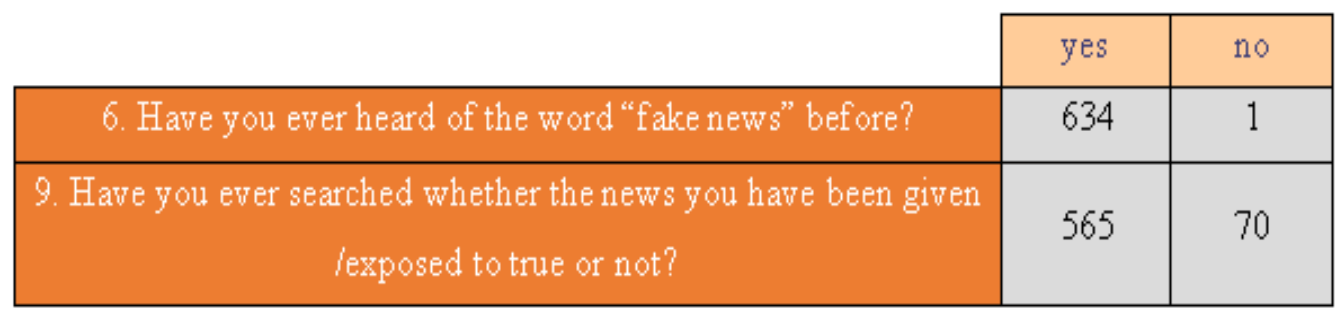

Figure6. Haveyou ever heard of the word "fake news" before?

In Figure 6 examines the awareness/familiarity of the participants with the term "fake news". 99.84\% of participants indicated that they heard "fake news". $88.98 \%$ of those stated that they have searched at least once whether the news they were exposed reliable or not, which seems to prove that there are knowledgeable people although they do not know anything about "post-truth" and though they generally spend time on social media in which they do not trust. 


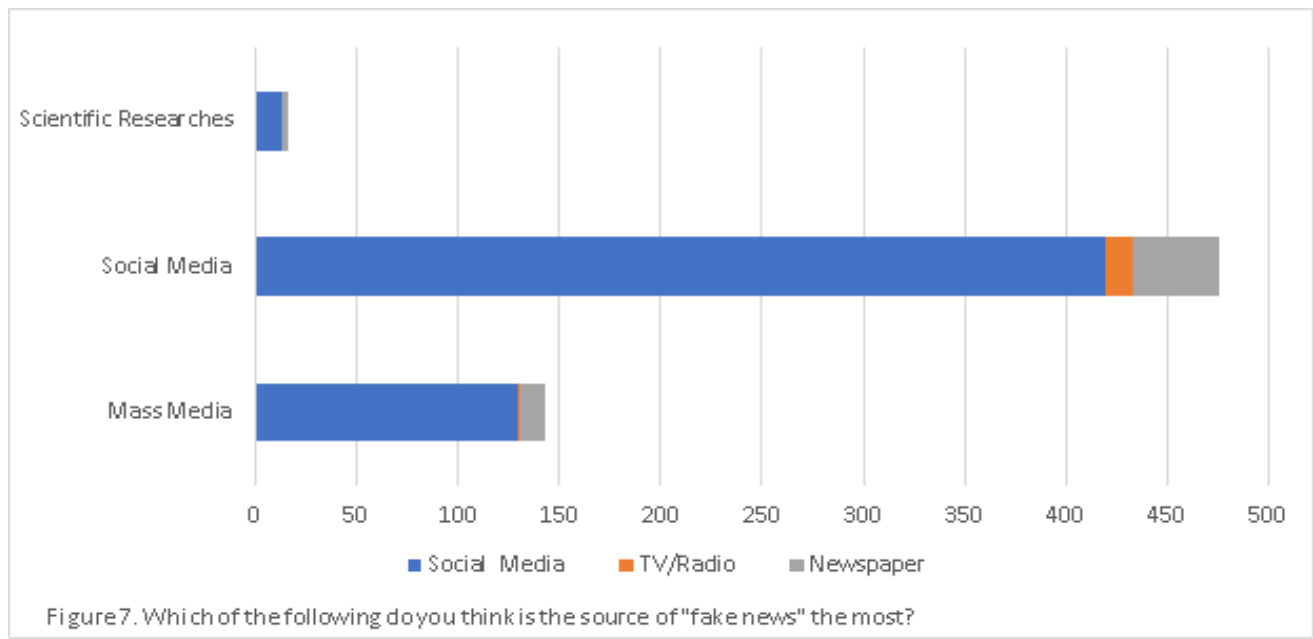

In Figure 7, 74.96\% of the participants indicated social and mass media as the source of "fake news." Yet, $88 \%$ of those indicated social media as the source of fake news. It seems evident that these participants also contribute to the spread of fake news as social media users (Figure 3). $22.52 \%$ of those stated mass media as the source of fake news, while $2.52 \%$ of those picked "scientific research" as their answer.

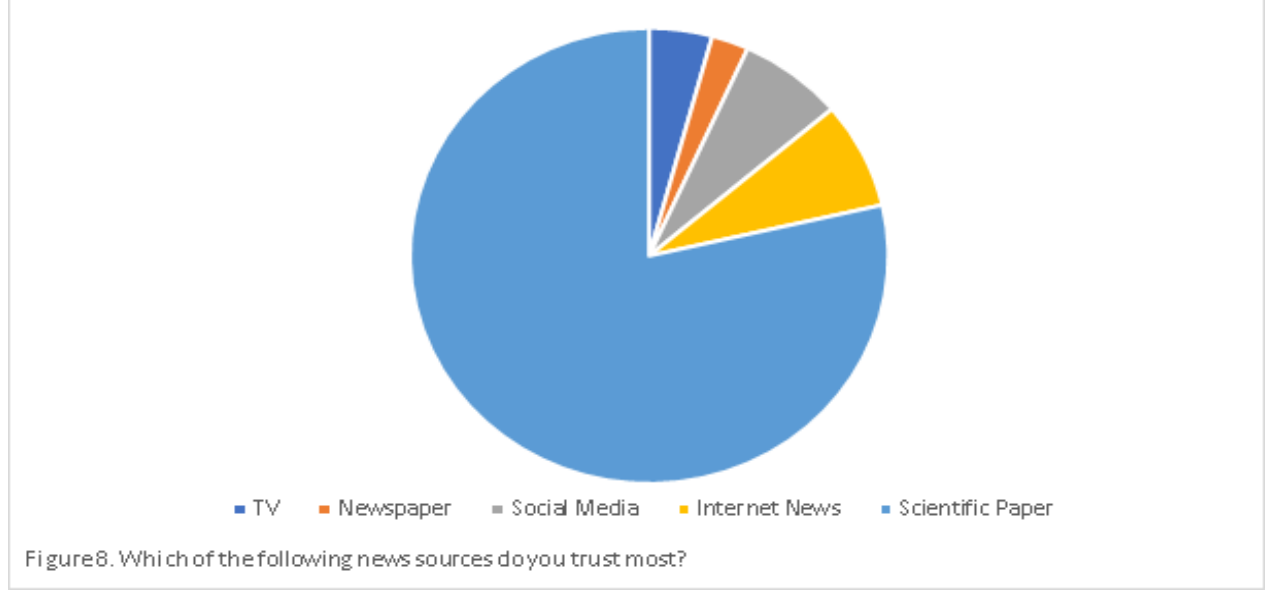

Figure 8 shows that participants generally trust scientific research/papers (78.58\%). And $7.56 \%$ of participants picked "Internet news" as the trustable source, while $7.09 \%$ of them trust social media platforms. They trust less in a scientific paper, $2.52 \%$. At a higher rate than the newspaper $(4.25 \%)$, they indicated TV as the most trustable medium. Figure 8 also indicates that although the participants spend a huge amount of their time on social media platforms, it proves that the most reliable source is research/papers.

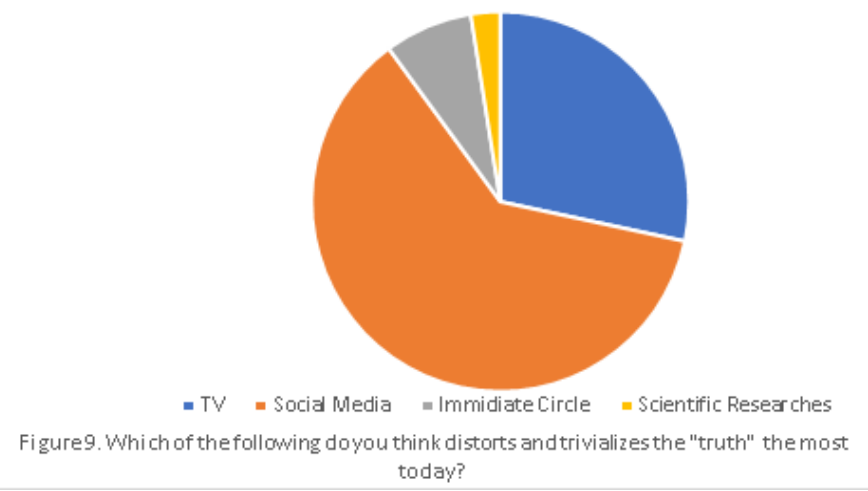

In Figure 9, 61.57\% of participants indicated that social media distorts and trivializes reality most, while $28.35 \%$ of those stated it as TV, radio, newspaper. The rate of the immediate circle is $7.56 \%$, and only $2.52 \%$ stated that scientific research/papers/books distorts and trivializes reality.

\section{\begin{tabular}{|l|l|l|}
\hline 雬 sssjournal.com & International Social Sciences Studies Journal & $\square$ sssjournal.info@gmail.com \\
\hline
\end{tabular}}




\section{FINDINGS AND DISCUSSION}

It seems evident that participants spend time on the internet and social media though they do not trust in the platform. The medium, which obscures and destroys reality, as the participants indicated, is, by a clear majority, social media. According to these findings, the most reliable source proves to be scientific researches/papers. Surprisingly, most of the participants do not know the term "post-truth" and 634 out of 635 participants are familiar with the concept of fake news. The participants also indicated that the platform on which they spend time the most is the source of fake news. As the participants are familiar with the concept of fake news and as they indicated that fake news is spread on social media, they, even limited participation, research the fake news exposed to them. As a result, the majority of participants spend time on social media platforms. Even if they do not trust these platforms, they help spread the fake news. It seems evident that there is a selective and conscious group, though limited number, tracking and factchecking fake news.

\section{CONCLUSION}

The term post-truth is known as hiding the known information and as ignoring the truth. Interviewing with Yalin Alpay, a political scientist, proved the possible effects of post-truth in a current and future world. Owing to the huge effects of Post-Truth, actual reality is structured by mass media. As a result of accepting this imaginary reality, people started to believe fake news day by day. Since it takes more and more places in our daily life in the 21st century, getting away from this imaginary reality will be harder (McIntyre, 2018, p.27). Jean Baudrillard argues that people create the truth according to their benefits. The societies are now ready to acknowledge their information from reading and hearing without asking whether it is true or not (Baudrillard, 1983, p.12). Thus, "post-truth age" research is generally based on the concept of fake news. Fake news's major aim is to alter society's ideas via shifted news; thus, it can divert them from reality. Mainly it is not about altering reality, it is just covering the information. This concept has a huge effect on people, and it's used by mass media and politicians (McIntyre, 2018, p.31).

This small-scaled research examines how much the participants, as social media users, are aware of the manipulative outcomes of fake news posted on social/mass media and screened on TV. The study indicates that people who participated in the survey usually trust scientific papers more than other sources. However, they spend their time on social media more than on reading scientific papers. And they face hundreds of news each day but there is no time to tract and research the truth and falsity of all of this news. In other words, there is a lot of information outpouring from social media and internet every day, and they are voluntarily or involuntarily forced to take information from social media and internet. As the survey proves, 450 out of 500 people prefer social media for news (fake or not). 73 percent of the participants have never heard of post-truth, and 9.7 percent of the participants indicate that they gather information from social media. In the post-truth era, social media users consume such contents as wholly fabricated stories and news without tracking the falsity and truth.

\section{SUGGESTIONS FOR FURTHER STUDY}

The researchers made several references in this study to obtain, learn and improve the societies' knowledge and awareness about post-truth and fake news. To gather detailed information, they carried out a survey, literature research and interviewed with the related author. To suggest, if the researchers conduct this study with a higher number of people, from a different country, different age groups, and different fields of occupations, the results can be more significant and reliable. Additionally, the researchers can add more questions to the survey so that they will achieve major results. Large-Scale research will necessarily prove a true perspective about the participants' awareness of or familiarity with post-truth, fake news.

\section{REFERENCES}

Ball, J. (2017) Post-Truth: How Bullshit Conquered the World. London: Biteback Publishing.

Baudrillard, J. (1983). In the shadow of the silent majorities; or, The end of the social, and otheressays; translated by Paul Foss, John Johnston, and Paul Patton. New York: Semiotext(e).

Baudrillard, J. (1995). Simulacra and simulation; translated by Sheila Faria Glaser. Ann Arbor: University of Michigan Press.

Kakutani, M. (2019). The death of truth. Tim Duggan Books. 
Keyes, R. (2004). The post-truth era: dishonesty and deception in contemporary life. New York: Martin's Press.

McIntyre, L. (2018). Post-truth. England: MIT Press.

McLuhan, M.(1967). Medium is the Message. England.

Oxford Learner's Dictionaries: Find definitions, translations, and grammar explanations at Learner's Dictionaries. (n.d.).

Retrieved

Oxford https://www.oxfordlearnersdictionaries.com/definition/english/post-truth?q=post truth. from

Zerfass, A., Tench, R., Verhoeven, P., Vercic, D., \& Moreno, A. (2018). European Communication Monitor 2018. Strategic communication and the challenges of fake news, trust, leadership, work stress and job satisfaction. Results of a survey in 48 countries. Brussels: $\quad$ EACD/EUPRERA, Quadriga Media Berlin.

\section{APPENDICES}

\section{A RESEARCH PROJECT: FAKE NEWS IN THE AGE OF POST-TRUTH}

We would like to invite you to participate in a research study that aims at collecting data for the abovementioned project topic as part of PROJ 201 offered by Foundation Development Directorate at Sabanc1 University in the Fall semester 2019. You will be asked to fill out a short survey that aims to investigate the relationship between people and their interaction with mass media, social media, and fake news. Please understand that your participation is voluntary. At no instance will you be asked to reveal any personal information. Participation in this study involves no significant risks whatsoever, be it political, physical, or emotional. Thank you in advance for your interest.

\section{There are 10 questions in this survey.}

1. What is your age?

Please choose only one of the following:
a. $18-25$
b. $26-35$
c. $36-45$
d. $46-55$

2. What is your gender?

Please choose only one of the following:
a. Female
b. Male
c. Other

3. What is the highest level of school you have completed?

Please choose only one of the following:
a. Primary School
b. Secondary school
c. Highschool
d. Bachelor's degree
e. Master's/Doctorate Degree

4. On which of the following do you spend more time?

Please choose only one of the following: 
a. Social media (Instagram, Twitter, Facebook, WhatsApp, etc.)

b. $\mathrm{TV}$, radio

c. Newspaper, magazine/journal, book/research

5. Where have you heard the "Post-Truth" concept first?

Please choose only one of the following:

a. Social media (Instagram, Twitter, Facebook, WhatsApp, etc.)

b. A book/research

c. A scientific paper

d. Immediate circle (family, work, school, friend)

e. I have never heard about this concept

6. Have you ever heard of the word "fake news" before?

Please choose only one of the following:

a. Yes

b. No

7. Which of the following do you think is the source of "fake news" the most?

Please choose only one of the following:

a. Mass media

b. Social media

c. Scientific researches

8. Which of the following news sources do you trust the most?

Please choose only one of the following:

a. TV

b. Newspaper

c. Social media (Instagram, Twitter, Facebook, WhatsApp, etc.)

d. Internet news

e. Scientific research papers

9. Have you ever searched whether the news you have been given /exposed to true or not?

Please choose only one of the following:
a. Yes
b. No

10. Which of the following do you think distorts and trivializes the "truth" the most today?

Please choose only one of the following:

a. $\mathrm{TV}$, radio, newspaper

b. Social media (Instagram, Twitter, Facebook, WhatsApp, etc.)

c. Immediate circle (family, work, school, friend)

d. Scientific research, papers, books 


\section{ARAŞTIRMA PROJESİ: HAKIKKAT SONRASI DÖNEMDE YALAN HABERLER}

Sabancı Üniversitesi Temel Geliştirme Direktörlüğü tarafından 2019 Güz döneminde sunulan PROJ 201 dersi kapsamında, yukarıda belirtilen proje konusu için veri toplamayı amaçlayan bir araştırma çalışmasına sizleri davet ediyoruz. Sizlerden insanların kitle iletişim araçları, sosyal medya ve sahte haberlerle olan ilişki ve etkileşimlerini araştırmayı amaçlayan kısa bir anket doldurmanız istenecektir. Katılımın kesinlikle gönüllü olduğunu belirtmek isteriz. Herhangi bir kişisel bilginiz talep edilmemektedir. Bu çalışmaya katılım, politik, fiziksel veya duygusal bir risk içermemektedir. İlginiz için şimdiden teşekkür ederiz.

\section{Bu ankette 10 soru var.}

1. Yaş aralığınız nedir?

Lütfen aşağıdakilerden yalnız birini seçin:
a. $18-25$
b. $26-35$
c. $36-45$
d. $46-55$

\section{Cinsiyetiniz nedir?}

Lütfen aşağıdakilerden yalnız birini seçin:
a. Kadın
b. Erkek
c. Diğer

3. En son mezun olduğunuz okul nedir?

Lütfen aşağıdakilerden yalnız birini seçin:
a. İlkokul
b. Ortaokul
c. Lise
d. Üniversite
e. Master / Doktora

4. Aşağıdakilerden hangisine daha çok zaman ayırmaktasınız?

Lütfen aşağıdakilerden yalnız birini seçin:

a. Sosyal medya (Instagram, Twitter, Facebook, WhatsApp vb.)

b. Televizyon, radyo

c. Gazete, dergi, kitap/inceleme

5. Hakikat sonrası dönem kavramını ilk kez hangi kaynaktan duydunuz?

Lütfen aşağıdakilerden yalnız birini seçin:

a. Sosyal medya (Instagram, Twitter, Facebook, WhatsApp vb.)

b. Konuyla ilgili bir kitap/inceleme

c. Bilimsel makale

d. Yakın çevre (aile, iş, okul, arkadaş)

e. Hiç duymadım

6. "Yalan haber" tabirini daha önce duydunuz mu?

Lütfen aşağıdakilerden yalnız birini seçin: 
a. Evet

b. Hayır

7. En önemli yalan haber kaynağı sizce hangisidir?

Lütfen aşağıdakilerden yalnız birini seçin:

a. Kitle iletişim araçları

b. Sosyal medya

c. Bilimsel araştırmalar/incelemeler

8. En çok hangi kaynaklardan ulaştığınız haberlere güveniyorsunuz?

Lütfen aşağıdakilerden yalnız birini seçin:

a. Televizyon

b. Gazete

c. Sosyal medya (Instagram, Twitter, Facebook, WhatsApp vb.)

d. Internet haberleri

e. Bilimsel araştırmalar/makaleler

9. Okuduğunuz, maruz kaldığınız veya size sunulan haberlerin hakiki olup olmadıklarını hiç araştırdınız mi?

Lütfen aşağıdakilerden yalnız birini seçin:
a. Evet
b. Hayır

10. Hakikatin önemsizleştirilmesine sizce en çok hangi kaynaklar sebep olmaktadır?

Lütfen aşağıdakilerden yalnız birini seçin:

a. TV, radyo, gazete

b. Sosyal medya (Instagram, Twitter, Facebook, WhatsApp vb.)

c. Sosyal çevre (aile, iş, okul, arkadaşlar)

d. Bilimsel araştırmalar, kitap, inceleme 